\title{
LÖKÖS ISTVÁN
}

\section{A ZÁGRÁBI TUDOMÁNYEGYETEM HUNGAROLÓGIAI TANSZÉKÉNEK TÖRTÉNETE*}

THE AUTHOR GIVES AN OVERVIEW ON THE HISTORY OF A QUARTER OF A CENTURY OF THE YOUNGEST FOREIGN WORKSHOP OF HUNGARIAN STUDIES, NAMELY, DEPARTMENT OF HUNGARIAN LANGUAGE AND LITERATURE OF THE FACULTY OF HUMANITIES OF THE UNIVERSITY OF ZAGREB. The education on Hungarian studies started in Zagreb in 1944 and was precedented. At the University of Zagreb the Hungarian Language Department was functioning as early as the second half of the $19^{\text {th }}$ century. Form 1904 to 1918, for almost one and a half century at the same place Hungarian language and literature was educated with the direction of professor Dr. Kazmér Greska. After the collapse of the Austrian-Hungarian Monarchy the representatives of the Croatian National Council radically put out professor Greska from the university and closed down the department. It was impossible to reorganize it in Yugoslavia between the two world wars. A new possibility came only after the independence of Croatia in 1994. The work in the department restarted on the basis of an interstate contract under the leadership of professor Dr. Milka Jauk-Pinhak and with the partnership of visiting teachers from Hungary. Today, under the management of Orsolya Žagar-Szentesi, 25-30 students start their studies at the department in each year. The function of the special college of translation of poetic works is outstanding. The department in 2002 celebrated the 900 years jubilee of the coronation of Kálmán Könyves as Croatian king with the representative volume of essays entitled Croato-Hungarica. The department was introduced in the "Hungarian issue" of the journal Književna smotra, the Zagreb journal of world literature in 2014 on the $20^{\text {th }}$ jubilee of the department. Their latest publication is With heart and Soull Dusom i srcem Hungarian-Croatian Somatic Phraseology/ Madarsko-hrvatski rječnik somatskih frazema (2018).

A Zágrábi Tudományegyetem Hungarológiai Tanszéke (Katedra za hungarologiju Sveučilišta u Zagrebu) a legfiatalabb, bár nem előzmények nélküli mühelye a magyarságtudománynak. A működését 1994-ben kezdő katedra mára nemzetközileg is jegyzett tudományos és oktatói műhely, amely szervesen illeszkedik a horvát felsőoktatás fellegvárának méltán nevezhető intézménynek, az egyetemnek a struktúrájába. A Zágrábi Tudományegyetem Bölcsészettudományi Kara (Filozofski Fakultet Sveučilišta u Zagrebu) működésének kezdetét az 1662-es esztendőre teszik. A jezsuita generális ekkor hagyta jóvá a rend zágrábi kollégiumában a filozófia oktatásának bevezetését. A királyi megerősítésre még hét esztendőt kellett várni: I. Lipót 1669-ben ismerte el és hagyta jóvá a stúdium megindítását. Újabb két esztendő elmúltával, 1671-ben, a Sabor (nemzetgyűlés) is szentesítette az I. Lipót adta privilégiumot. Mint ismeretes, 1773-ban XIV. Kelemen pápa felfüggesztette a rend működését, így ezt követően Josip Galjuf zágrábi püspök a jezsuiták helyett világi papokra bízta a kollégium müködtetését, $s$ ettől kezdve külön előadója van a teológiai és a bölcseleti stúdiumnak. 1776 újabb fontos eseményt

* A szerző 2018. febr. 16-án munkássága elismeréséért megkapta a Horvát Köztársaság Hajnalcsillag Rendje kitüntetést, amely a külföldieknek adható legmagasabb horvát kitüntetés. Folyóiratunk szerkesztősége szívből gratulál a kitüntetéshez. 
hozott: Mária Terézia döntése nyomán Királyi Akadémia létesült Zágrábban, amelynek keretében az alábbi diszciplínák kaptak katedrát: kísérleti fizika és mechanika, logika, metafizika, morálfilozófia, filozófiatörténet, matematika, geometria, architektúra, „hidrotechnika”, egyetemes történet, irodalomtörténet. 1777-ben a Ratio Educationis szabályozta az oktatás rendjét, ettől kezdve négy katedra keretében zajlott az oktatás napi négy órában (délelött és délután 2-2 óra).

Ezt követően újabb változás csak az 1861-1868 közötti években történt. 1861-ben és 1867-ben a Sabor feliratban kérte I. Ferenc Józseftől egyetem alapítását zágrábi székhellyel. A király végül 1869. április 8-i dátummal „szankcionálta” a Zágrábi Tudományegyetem (Sveučilište u Zagrebu) alapításáról szóló törvényt. 1874. január 13-án I. Ferenc József törvényi szentesítéssel engedélyezte három fakultás, a Bölcsészettudományi (Mudroslovni), Filozófiai-történettudományi (Filozofičko-historijski) és a Matematikai-természettudományi (Matematičko-prirodoslovni) Kar működését. A karokon 1874. szeptember 20-án az alábbi tanszékeken 26 hallgató kezdte meg tanulmányait: Elméleti és Gyakorlati Filozófia-filozófiatörténeti, Egyetemes Történeti, Szláv Filológiai, Klasszikus Filológiai Tanszék. Az egyetem első rektora Matija Mesić, a Bölcsészettudományi Kar első dékánja Franjo Marković volt, az univerzitás ünnepélyes megnyitására 1874. október 19-én került sor.

A megnyitást követően, a 19. század utolsó negyedében a zágrábi univerzitás az oktatott tudományszakok spektrumának látványos bővülésével büszkélkedhetett. Az ókortudomány, a szláv filológia, a történettudomány és a bölcselet mellett a hetvenes évtized második felében megkezdi működését a Művészettörténeti és az Archeológiai Tanszék, 1878-ban a Szláv Filológiai Tanszék keretében a Russzisztika, 1882-től francia, olasz, 1895-től német, 1898-tól angol lektor tart rendszeresen kurzusokat. Ez utóbbi nyelvek lektorátusai hamarosan tanszékekké szerveződnek, 1908-ban megalakul az Indoeurópai-komparatisztikai Tanszék, s ugyanez évben kap kinevezést a magyarságtudomány körében is publikáló kiváló albanológus professzor, Milan Šufflay a Történelem Segédtudományi Tanszék élére. ${ }^{1}$

Ebben az egyetemi sruktúrában és kontextusban jelenik meg a hungarológia mint diszciplína és bölcsészképző szak, jóllehet kezdetben alig jelentett többet kezdő és haladó nyelvi kurzusnál. Erre utal az első, ma ismert adat is, mely szerint 1880-ban megalakult a magyar nyelvi lektorátus. ${ }^{2} 1892$-től viszont már - a hivatalos iratok szerint - müködik a Magyar Nyelv és Irodalom Tanszék (Katedra za mađarski jezik i književnost). Tanszékvezetőről ugyan még nem szól a krónika, a státusz betöltése majd csak 1902-ben történik meg Greksa Kázmér, akkor pécsi illetőségű cisztercita szerzetestanár pályázatának elfogadásával. ${ }^{3} \mathrm{Az}$ időpont már a biztató jövő ígérete. Greksa professzor működé-

${ }^{1}$ Stjepan Damjavnović, urednik, Filozofski fakultet Sveučilišta u Zagrebu: Monografija (Zagreb, 1998), $13-15$.

2 Milka JaUK-PinHAK, „Hungarológiai szak a Zágrábi Egyetemen”, in Croato-hungarica: Uz 900 godina hrvatsko-madarskih povijesni veza. A horvát-magyar történelmi kapcsolatok 900 éve alkalmából. Katedra za hungarologiju Filozofskog fakulteta Svučilišta u Zagrebu - Matica hrvatska (Zagreb, 2002), 11.

${ }^{3}$ Uo. 
sével ugyanis másfél évtizedes folyamat kezdődik, amely az Oszrák-Magyar Monarchia összeomlásáig ível. Ezt a periódust bátran nevezhetjük a horvátországi hungarológia Greksa-korszakának. S mert Greksa professzori működése a Bölcsészettudományi Kar oktatási struktúrájában a hungarológián kívüli területekre is kiterjedt, s dékánként, majd prodékáni minőségben a kar egészének munkájában is részt vállalt, zágrábi professzorságának bemutatása mellett mindenképp indokolt életpályája egészére is kitekinteni.

Greksa 1864. december 23-án született Pécsett, iparos családban. ${ }^{4}$ Elemi iskoláit elvégezve tanulmányait a ciszterciták gimnáziumában folytatta, $s 16$ éves korában maga is a rend tagjainak sorába lépett. A noviciátust Zircen töltötte, majd - a gimnáziumi stúdiumokat befejezendő - a rend egri gimnáziumába ment 1882-ben. (Tanári működését is Egerben kezdi majd 1886-ban.) 1883-ban a budapesti egyetem magyar-latin szakos hallgatója lesz. 1884-ben szentelik pappá, egy év múlva pedig elöljárója a rend székesfehérvári gimnáziumába helyezte. 1890-ig letette egyetemi vizsgáit s le is doktorált, értekezését 1891-ben intézménye értesítőjében adta közre $A$ Zrynyiász és viszonya Tasso-, Vergilius-, Homeros- és Istvánffyhoz címmel. ${ }^{5}$ Dolgozatát Beöthy Zsoltnak ajánlva annak „közelebbi tárgyáról” ezt írta: a munka „a [...] (XIV-XV) énekeknek [...] kidolgozását foglalja magában [...], mely létét - kedves kötelességemnek tartom kijelenteni - Gyulai Pál kiváló tudósunk serkentésének és folytonos útmutatásának köszöni”. ${ }^{6}$ Greksa filológiai erényeit dicséri - emeli ki Kiss Gy. Csaba -, hogy a címben említett szerzők művein túl Ariosto, Voltaire, Klopstock és Milton munkáinak kontextusában vizsgálja a magyar költő eposzát, s ezek után aligha tekinthető véletlennek, hogy később „[...] Homérosz néhány hasonlatának vándorlásáról értekezett az Irodalomtörténeti Közleményekben". ${ }^{7}$

Greksa életútjának újabb szakasza - mint említettük - ismét Egerhez kötődik, a rend egri fógimnáziumának tanára lesz, ahol tudományos munkája mellett műfordítással, énekszerzéssel is foglalkozik. Lányi Ernő karnaggyal ima- és énekgyüjteményt szerkeszt a katolikus tanuló iffúság számára Cantate címmel. Érdemes megemlíteni: Lamartine-fordításait a Katholikus Szemle közölte 1898-ban. ${ }^{8}$

A tudós tanár Greksa pedagógusként is jeles képviselője a méltán híres tanítórend tanártípusának. Pedagógusi erényeit és értékeit olyan nagy hírnévre szert tett diákjai tanúsítják, mint gróf Klebelsberg Kunó vagy Babits Mihály. Kiss Gy. Csaba idézi a Tímár Virgil fia című Babits-regény alábbi, a tanár Tímár Virgil alakját megjelenítő sorait, akinek modellje Greksa Kázmér volt: a refektóriumban „lentebb ül, szerényen, a tiszteletreméltó Tímár Virgil. A házfönök szeretettel nyugtatja meg szemét a legjobb tanár,

\footnotetext{
${ }^{4}$ Az életpálya adatait Kiss Gy. Csaba Greksa Kázmér pályájának magyarországi szakaszáról címü kéziratos dolgozatából vesszük.

${ }^{5}$ A ciszterci rend székesfehérvári katholikus fögimnáziumának értesitóje az 1890-91. iskolaévröl, Székesfehérvár, 1891., 1-158.

${ }^{6}$ Uo., 117.

7 Kiss, Greksa Kázmér...

${ }^{8}$ Uo.
} 
az igazi szerzetes becsületes arcán. [...] Tímár Virgil bort nem ivott, a kártyát nem szerette, könyvei mellett egészen az iskolának élt."

A szépíró rajzolta képet a rendtárs és jeles irodalomtörténész, Brisits Frigyes szavai színezhetik: "Tehetségének tartozunk azzal, hogy megemlékezünk róla. Idös rendtársaim úgy beszéltek róla, hogy messze visszamenöleg nem tudnak senkit, akinek nagyobb tehetsége lett volna. [...] Tragikus ember volt. Egész életében szellemes ötletekben sziporkázta szét szavai hitelét."10 $S$ hogy a tudós tanár portréját még tovább árnyaljuk, az Irodalomtörténet 1921-ben közölt nekrológjából Idézünk: „Tudományos foglalkozásán kivül fontos politikai szolgálatokkal is segiti a magyarság ügyét. 1918-ban a horvát elszakadás idején menekülni kénytelen az elfogatás elöl. Sok [...] hánykódás után Budapestre jön s a [...] kolozsvári egyetemen folytatja müködését. [...] Kéziratban maradtak: egy horvát-magyar szótár, horvát nyelvtan. Kéziratainak legnagyobb része Zágrábban maradt. Ezek tartalmáról, sorsáról semmit sem tudunk."11

De térjünk vissza most Greksa zágrábi professzorságához. Az agrami hungarológus Greksa pályája lényegében 1892-ben kezdődik. A magyar tanszék alapításának szükséges voltáról ugyanis már 1892-t megelőzően hosszabb ideje zajlott a disputa, amely az említett évben professzori pályázat kiírásával zárult. Akkor, a határidő lejártáig, két pályázó jelentkezett: Dragutin Pfann zágrábi gimnáziumi tanár és dr. Ivan Bojničić állami levéltáros, aki már két év óta tartott magyar nyelvtanfolyamot kezdőknek és haladóknak a Bölcsészettudományi Karon, emellett magyar nyelvtörténeti speciálkollégiumot is. A kari vezetés a pályázatot végül eredménytelennek minősítette, azzal az indoklással, hogy a pályázók egyike sem végzett érdemi tudományos munkát, ami az egyetemi oktatói munka hatékonyságának elengedhetetlen feltétele. Az indoklással a professzori kar maximálisan egyetértett, s a dékánnak azt javasolta: forduljon Budapesthez, s kérje a magyar kollégákat, „nevezzenek meg valamely taneröt, aki rendelkezik a szükséges tudományos felkészültséggel [...]"12 Bojničić a döntést sértőnek találva lemondta előzőleg meghirdetett "A magyarok eredetérôl” című kollégiumát, ám a nyelvi kurzusok vezetését továbbra is vállalta, egészen 1918-ig - időnként kiegészítve oktatói tevékenységét néhány választható kollégiummal. Bojničić 1892-ben habilitációs kérelmet is benyújtott, de a Kari Tanács - a Tadija Smičiklas vezette bizottság (tagjai: Natko Nodilo és Petar Marković) döntésére hivatkozva - azt elutasította, azzal a megjegyzéssel, hogy amennyiben a későbbiekben az oklevéltan körébe tartozó tudományos dolgozatot publikál, kérelme pozitív elbírálásban részesülhet. Ismereteink szerint ez nem

9 BABITs Mihály, Tímár Virgil fia (Budapest [1922], 2001), 11.

${ }^{10}$ Idézi Kiss Gy. Csaba: Greksa Kázmér..., Brisits Frigyes, Az én tanáraim a pécsi gimnáziumban (Pécs, 1933), 74-75.

${ }^{11}$ Idézi Kiss Gy. Csaba: Greksa Kázmér..., „Nekrológ (Greksa Kázmér)”, Irodalomtörténet 1. sz. (1921): 90.

12 Damir Agrčić, „Kazimir Grekša, profesor mađarskog jezika i književnosti na Sveučilištu Franje Josipa I. u Zagrebu (1903-1918)", in Varietas Europica Centralis: Tanulmányok a 70 éves Kiss Gy. Csaba tiszteletére, szerk., if. BertÉnYI Iván, Géra Eleonóra és MÉsZÁros Andor (Budapest: ELTE Eötvös Kiadó, 2015), 24-25. 
történt meg. Néhány év múltán Bojničić címzetes rendkívüli egyetemi tanári címet kapott, katedrát viszont nem. ${ }^{13}$

E huzavona után újabb pályázatot csak 1901-ben írtak ki. Ezúttal népesebb volt a pályázók mezőnye. Damir Agičić adatai szerint a pályázók között volt Horváth Cirill, a budapesti evangélikus gimnázium, dr. Körösy Sándor, a budapesti VI. kerületi fögimnázium, dr. Szegedy Rudolf, a pécsi állami reálgimnázium, Blagoje Brančić, az újvidéki szerb fogimnázium és dr. Piszarević Sándor, a szarajevói fógimnázium tanára. Dr. Greksa Kázmér pécsi cisztercita fogimnáziumi tanár utólag küldte be pályázatát, s a bizottság, amelynek tagjai dr. Milivoj Šrepel, a latin nyelv professzora, dr. Tomo Maretić, a horvát nyelv professzora és dr. August Musić, a görög nyelv professzora (mindhárman a kor horvát tudományos életének reprezentánsai) Greksa pályázatának elfogadása mellett döntött. E döntés kapcsán Kiss Gy. Csaba felteszi a kérdést: „Vajon mi szólhatott a pécsi szerzetes tanár mellett?" Válasza hipotetikus, ám elgondolkodtató: „Érdemes eltünödni azon a mellékkörülményen [...], hogy a pécsi cisztercita fögimnáziumban Greksa tanársága idején jârt Khuen-Héderváry bánnak Károly nevü idösebbik fia (az 1898-99-es évben a VIII. osztály tanulója volt). Vajon teljesen képtelen volna az a föltételezés, hogy a horvát nemzeti mozgalom által satrapának tartott bán [...] informálisan támogathatta a jelöltek közül a horvátul is tudó kitünö pécsi tanárt?"14 Khuen-Héderváry Károly 1883 és 1903 között volt a horvát báni tisztség birtokosa. Báni regnálásának megítélése a korabeli horvát politikai élet, $s$ később a horvát történetírás szerint - eufemisztikusan fogalmazva is - elmarasztalandó, jóllehet, regnálása húsz esztendeje alatt a horvát gazdasági élet kedvező irányba lendült, s Zágráb e két évtized alatt nőtt európai nagyvárossá. E két évtized tárgyszerü megítélésével - úgy tűnik - máig adós a horvát történetírás, $s$ csak örvendezhetünk a horvát identitású, de egyben magyar történész, Sokcsevits Dénes rajzolta tárgyilagos képnek, amelyben a Khuen-Héderváry-korszakként aposztrofált horvát történelmi időszakaszt bemutatja. Khuen-Héderváryt „[...] Ferenc József $[\ldots]$ nem azért küldte az 1883. évi véres zavargások után Horvátországba, hogy »eltörölje a horvát nemzet nevét" - irja, hanem azért, hogy megszilárditsa a dualizmus politikai rendszerét. Rendet teremtsen [...] és a magyar-horvát kiegyezés ellen még mindig berzenkedo" horvát közvéleményt megbarátkoztassa az 1868-as kompromisszumból fakadó magyar viszonylatokkal. A fiatal bán határozottan és energikusan látott hozzá célkitüzései megvalósitásához, kemény eszközöket alkalmazott a dualista rendszer ellenfeleivel szemben." számos, a közvéleményt irritáló intézkedése volt. Ezek skálája a választási manipulációktól a gyülekezési tilalmon át a sajtószabadság korlátozásáig terjedt. ${ }^{16}$ Intézkedéseit azok a reformok sem tudták ellentételezni teljes mértékben, amelyek a gazdaság prosperálását vagy éppen az oktatás korszerüsítését eredményezték. Pedig nem csekély,

${ }_{13}$ Uo., 25.

${ }^{14}$ KIss, Greksa Kázmér...

15 SoKcsevits Dénes, Horvátország a 7. századtól napjainkig (Budapest: Mundus Novus, 2011), 397.

${ }^{16}$ Uo. 
a közjót szolgáló hozadékról volt szó. Elég például az oktatási reformokra emlékeztetni: a gimnáziumok, reáliskolák, az ipari szakiskolák fejlesztése vagy éppen a nők egyetemi képzésének lehetőségére. A gazdaság „ugrásszerü fejlödést mutatott”, az életszínvonal, a közegészségügyi helyzet javult, növekedett a népesség, a tudomány és a kultúra látványos fejlődést mutatott, $s$,impozánsnak mondható az egyetemi hallgatók létszámának növekedése". 1875 és 1910 között teológiai, jogi, bölcsész-, természettudományi képzésben, valamint a gyógyszerészeti, erdészeti, geodéziai szakon mindösszesen 1179 hallgató tanult. ${ }^{17} \mathrm{~A}$ kulturális és művészeti élet szférájában a bán segítője a horvát történetírásban még ma is csak visszafogottan emlegetett kultúrpolitikus - lényegében vallási és oktatásügyi miniszter - az író, műtörténész, etnográfus Isidor Kršnjavi volt, aki a horvát művészet addig nem tapasztalt mecenatúráját teremtette meg: sport, természetjáró és kulturális egyesületek, múzeumok alapítója volt. ${ }^{18}$

Az ellenzék mindezek ellenére sem tolerálta a bán közéletet korlátozó-reformáló intézkedéseit, egyre renitensebb akciók generálójaként provokálta a hatalmat. Mindez odavezetett, hogy az egyetemi ifjúság 1895-ben a király zágrábi látogatásakor nagyszabású tüntetést rendezett, $s$ nyilvánosan elégette a magyar zászlót. Az új évszázad első éveiben a báni intézkedések fakasztotta magyarellenesség tovább fokozódott, s 1903-ban véres tüntetéssel tetőzött. A MÁV zágrábi igazgatósági épületére kifüggesztett magyar nyelvű felirat főleg a diákságot irritálta, s bár a feliratot erőszakkal eltávolították, a tüntetés eszkalálódott, a demonstrálók az ország függőségének megszüntetését, sajtószabadságot, új választójogi rendszert követeltek. Zágrábban a tüntetők a pályaudvar berendezéseit összetörték, ablakait bezúzták. A rendőrség a tüntetést szétverte, a gyüléseket betiltotta. A megmozdulások vidékre is átterjedtek, ami a magyar zászló elégetését $s$ a magyar érzelmű tisztviselők bántalmazását jelentette. Kunovacon karhatalmi sortűz is eldördült, amelynek 23 áldozata volt. ${ }^{19}$

Héderváry 1903-ban távozott a báni székből, ezt a kortársak, majd később a horvát történetírás ellenzéki győzzelemként $s$ a bán bukásaként aposztrofálta. A valóság más volt, távozásának okát Sokcsevits Dénes fogalmazta meg pontosan: Khuen-Héderváry „[...] nem vált bukott politikussá, a báni székböl kizárólag azért távozott, mert kinevezték Magyarország miniszterelnökévé". ${ }^{20}$

Ebben a zaklatott politikai-közéleti közegben kezdte meg müködését a Zágrábi Egyetem Bölcsészettudományi Karán a Magyar Nyelv és Irodalom Tanszék magyarországi illetőségű professzora, Greksa Kázmér. Az egyetem, ezen belül a Bölcsészettudományi Kar vezetésének aktivitása a tanszék szervezésében, a professzori pályázat meghirdetésében s Greksa kinevezésében a politikai elfogulatlanság és pártatlanság példája volt.

17 Uo., 411-413.

${ }_{18}$ Uo., 413; KIss Gy. Csaba, Budapest-Zágráb: Oda-vissza (Budapest: Nap Kiadó, 2015), 148.

19 Soкcsevits, Horvátország..., 416; Ferdo Šišıć, Pregled povijesti hrvatskoga naroda (Zagreb: Matica hrvatska, 1962), 460-462; Vaso Bogdanov, Hrvatski narodni pokret 1903/4. (Zagreb, 1961); PerÉNYI József és Arató Endre, Jugoszlávia története (Budapest: Felsőoktatási Jegyzetellátó, 1961), 216-217.

20 SoKcsevits, Horvátország..., 417. 
Miként az is, ahogyan Greksa állásának késedelmes elfoglalását kezelték. Betegsége miatt ugyanis csak 1903 novemberében érkezett meg Zágrábba, s máris egyéves szabadságot kért, kérelmét azzal indokolva, hogy „horvát nyelvtudását kívánja tökéletesíteni”. A dékán teljesítette Greksa kérését, aki így csak az 1904/5-ös tanév kezdetén foglalta el katedráját. Az oktatómunkát a téli szemeszterben kezdte meg.

A kezdetkor, de még később is, a hallgatóság érdeklődése a magyar nyelv és irodalom szak iránt gyér volt. Olyannyira, hogy óráit gyakran saját lakásán tartotta. Az érdeklödés hiányáról több ízben informálta a kari vezetést, ám a helyzet ennek ellenére sem javult, amit a horvát politikai ellenzék és a közvélemény s még inkább az ellenzéki sajtó magyarellenes propagandája is magyarázhat. Jellemző, hogy a kor európai műveltségű költője, a horvát Adyként is aposztrofálható Antun Gustav Matoš a Háromegy Királyság „kulturális autonómiája” „elleni merényletnek” nevezte a tanszék megalapítását. ${ }^{21}$ A magyarellenes közhangulat példája ebben az időben a kor népszerü prózaírójának, Ksaver Šandor Gjalskinak 1902-ből való szatirikus kisregénye, az „Izlet Grinczinger Pála na Magyar Tenger" (Grinczinger Pál utazása a Magyar Tengerre), amely a Fiume hovatartozása körüli politikai csatározások és a vasútnál, a postánál, a pénzügyi tisztviselői állások betöltésénél szorgalmazott és kötelezővé tett magyar nyelvtudás körül zajló poltikai viták reflexiója. ${ }^{22}$

Hogy a hallgatóság bojkottálta-e a Greksa-előadásokat, miként tette azt Milan Šufflayval, nem tudni. ${ }^{23}$ Nyilván a kari vezetés jóváhagyásával - a problémákat áthidalandó - a magyar nyelv, irodalom és kultúra tárgyköre mellett Greksa rendszeresen tartott kollégiumokat az általános filológia, a stilisztika, a finn nyelv, a humanizmus kori irodalom tárgyköréből. Missziós feladatának tekintette emellett a költő Zrínyi Miklós életének és magyar írói munkásságának ismertetését $s$ a horvát-magyar irodalmi kapcsolatok kérdéskörének rendszerező tárgyalását. ${ }^{24}$

A tanszéki oktatói munka mellett részt vett a kari vezetés munkájában is, s e munka elismeréseképpen lett az 1910/11-es tanévben a Bölcsészettudományi Kar dékánja, majd udódának, Ferdo Šišićnek prodékánja az 1911/12-es tanévben. A kari munkán kívül - kormánymegbízás alapján - tankönyvreferensként a magyar tankönyvek és egyéb kiadványok minősítését is végezte, amelyeket az iskolákban magyar nyelvű tankönyvekként használtak. ${ }^{25}$

Bölcsészkari kollégáinak közösségében nagyra becsülték szakmai felkészültségét, segítőkészségét, a kari tudományos életben vállalt aktív szerepét. Ízig-vérig zágrábi polgár $s$ egyetemi tanár lett, ezért is érintette fájdalmasan „kiűzetése” Zágrábból az 1918-as impériumváltozást követően. ${ }^{26}$ Ennek körülményeit Damir Agičić vizsgálta tüzetesen:

${ }^{21}$ KIss, Oda-vissza, 37.

${ }^{22}$ LőKös István, Ksaver Šandor Gjalski (Budapest: Eötvös József Könyvkiadó, 2008), 120-122.

${ }^{23}$ KIss, Oda-vissza, 38.

24 AgIČIĆ, „Kazimir Grekša...”, 25-26.

25 Uo., 26.

26 Uo., 26-27. 
„Az Osztrák-Magyar Monarchia öszeomlása idején, s az azt közvetlenül követö napokban, az olyan némaságba dermedt idöben, amikor mindenféle cselszövök és lármázók is felbukkannak, Zágrábban is megjelent a spanyolnátha és néhány "felböszült" ember, a müvelt világ pedig magánélete szférájába húzódott vissza, vagy elindult valamerre jobb szerencsét remélve a horvát fövárosból, s egyeteméröl számüzték a magyar nyelv és irodalom elsö professzorát, a ciszterci rend tagját. " ${ }^{27}$ Greksa az említett vészterhes napokban a végzősök záróvizsgáját követően (a vizsgabizottság tagja volt), súlyosan megbetegedett spanyolnáthában. Magas lázzal feküdt felsővárosi (gornji grad) lakásán, ahol váratlanul megjelentek a Szerb-Horvát-Szlovén Nemzeti Tanács képviselői és felszólították, azonnal adja be nyugdíjazási kérelmét, mert Horvátországban nincs szükség többé a magyar tanszékre. Amennyiben nem tesz eleget a felszólításnak, mint a horvát nemzeti érdekeket sértő magyar kémet fogják letartóztatni. Greksa, súlyos betegen, legszemélyesebb dolgait összecsomagolva s értékes kéziratait, könyveit hátrahagyva, űzött vadként menekült Pécsre. Menekülése körülményeit kedves zágrábi kollégájának, barátjának, a későbbi jeles nyelvész professzornak, Stjepan Ivšićnek írott levelében közölte: „El kellett hagynom Zágrábot, hogy mentsem egészségemet, s talán az életemet is, oly gyorsan, hogy arra sem maradt idöm, hogy teljesitsem legkedvesebb kötelességemet: elbúcsúzzak szeretett barátaimtól." Elüzetése alighanem élete legfájdalmasabb élménye lett. Öt, aki sohasem politizált, nem forgolódott magas rangú politikusok környezetében, a választások alkalmával távolmaradásával kívánta kifejezni apolitikusságát, most kémkedéssel gyanúsítják. „Szörnyü módon megalázták és vérig sértették”, s még halállal is megfenyegették. Ennek ellenére közel másfél évtized tapasztalásai, horvát kollégái barátsága, kevés számú, de tudását, emberi közvetlenségét mindenkor méltányoló tanítványai ragaszkodása nyomán meggyőződéssel vallotta: mindazt, ami vele 1918-ban történt, nem a horvát nép fiai követték el, „mindig nagyon öszintén szeretett és szivböl szeretni fog, azt remélve, az "eszelös "idö nem tart örökké, eltünik a gyülölet, s visszatérhet Zágrábba. Barátjának, Stjepan Ivšićnek irta: "nagyon akartam horvátul is alkotni, amikor érzékeltem, hogy nyelvi nehézségeim ellenére is tudok hamarosan olyan gyorsan irni, miként anyanyelvemen."” Nagy tervei voltak: „Meg akartam irni a horvát nyelv filozófiáját, [...] a nyelv fiziológiáját, a nyelv pszichológiáját, esztétikáját, logikáját, eredetét, keletkezését, fejlödését, történetét, a rokonnyelveket, a dialektusokat." További terve volt az ószláv személynevek történeti vizsgálata, $s$ lefordítani magyarra „a legszebb horvát verseket” ${ }^{28}$

1918 őszén a magyar-horvát perszonálunió nyolc évszázados történetének lezárultával a Zágrábi Egyetem Bölcsészettudományi Kara szegényebb lett egy tanszékkel: a papírforma szerint 1892 óta negyedszázadon át létező, de professzúrával csak 1902 óta rendelkező zágrábi egyetemi Magyar Nyelv és Irodalom Tanszék első korszaka lezárult. A két világháború közötti negyedszázadban, az antant segítségével összetákolt új délszláv államban (előbb Szerb-Horvát-Szlovén Állam, majd Szerb-Horvát-Szlovén

27 Uo., 23.

${ }^{28}$ Uo., 23-24. 
Királyság, végül Jugoszláv Királyság) szó sem lehetett a katedra újjászervezéséről, és - tudomásunk szerint - a királyi Jugoszlávia összeomlása után megalakult Független Horvát Állam (NDH, azaz: Nezavisna Država Hrvatska) sem gondolt erre. A szocialista Jugoszlávia létrejötte után is csak másfél évtized elmúltával kapott katedrát a térségben a hungarológia: Újvidéken, a Belgrádi Egyetem filiájaként működő Bölcsészettudományi Karon alakult meg az új magyar tanszék. Persze egy szóval sem említve az egykori zágrábi előzményt. Az új intézmény célja, feladata nem csupán „a magyarság, [...] hanem Jugoszlávia közös szocialista kultúráját [...] kell, hogy szolgálja [...]”- olvassuk az első tanszékvezető, Sinkó Ervin székfoglalójában. ${ }^{29}$ Természetesen az akkori jugoszláviai marxista eszmei-politikai rendszer igényeihez és elvárásaihoz igazodva. Sinkó zágrábi lakos volt, magát horvát és jugoszláv íróként is meghatározta, s a tanszék élére feltevésünk szerint - Krleža messzemenő támogatásával került, annak ellenére, hogy az egykori tizenkilences kecskeméti vörös városparancsnok érettségivel sem rendelkezett. A tanszék Újvidékre helyezése a délvidéki, azaz bácskai és bánáti térségbeli, akkor még mindig több százezres magyar lakosság igényeinek figyelembevételével történt. Zágrábhoz - Sinkó zágrábi lakos mivoltán kívül - semmi köze sem volt. További története nem tárgya e dolgozatnak. A zágrábi egyetemi hungarológiai műhely újjászervezésére csak Horvátország függetlenné válása után nyílt lehetőség. Nem előzmények nélkül, a múlt század hatvanas éveitől kezdve ugyanis lektorátusi szinten már volt magyar nyelvoktatás, a hallgatóság fakultatív tárgyként tanulhatta nyelvünket. Egyes filológiai szakok hallgatói mellett történész, néprajz és egyéb szakos hallgatók is felvették. A lektori teendőket végző tanárokat államközi egyezmény alapján Magyarország akkreditálta, s ez a gyakorlat működött a Hungarológiai Tanszék megalakulásáig. A magyar nyelvi lektorátus a Bölcsészettudományi Kar Általános Nyelvészeti és Orientalisztikai Tanszékéhez tartozott. A lektorátust a belgrádi magyar nagykövetség támogatta könyvekkel, $s$ e támogatás révén jött létre a későbbi tanszéki könyvtár alapgyűjteménye.

A lektorátus működtetése mellett a horvát állam függetlenné válása előtt is történtek kísérletek az egykori Magyar Nyelv és Irodalom Tanszék újjászervezésére. Olyan kiváló akadémikusok-professzorok szorgalmazták, mint Radoslav Katičić, Vojmir Vinja, Željko Bujas, August Kovačec, ám törekvésük zátonyra futott: a hatalom az újvidéki Hungarológiai Tanszék létezésére hivatkozva utasította el a kérelmet. ${ }^{30}$

A hungarológiai szak és tanszék alapításának gondolata és igénye 1993-ban került napirendre ismét, amikor a Horvát Köztársaság Tudományos Minisztériuma, személyesen dr. Ilija Škrinjarić miniszterhelyettes s a Magyar Köztársaság nagykövetsége, személyesen Bagi Gábor nagykövet, a Zágrábi Egyetem részéről pedig dr. Marijan Šunjić rektor kezdeményezésére a tanszékalapítás a megvalósulás stádiumába jutott. ${ }^{31} \mathrm{Az}$ elökészítő megbeszélések szorgalmazója Bagi Gábor volt, aki korábban főkonzul, a független

\footnotetext{
${ }^{29}$ Sinkó Ervin, Magyar irodalom, Tanulmányok I (Újvidék: Fórum Könyvkiadó, 1961), 6.

${ }^{30}$ Jauk-PinhaK, „Hungarológiai szak... ”, 12.

31 Uo.
} 
Horvátország létrejötte után nagykövetként képviselte Magyarorzágot Zágrábban. Horvátország 20. századi történelmének vészterhes napjaiban nem kis jelentősége volt a függetlenné vált állam magyar részről történt elismerésének, s a segítségnek, amelyet a Magyar Köztársaság kormánya nyújtott abban a véres küzdelemben, amelyet a horvátok a jugoszláv hadsereg egységeivel és a szerb szabadcsapatokkal vívtak. Ez a kiállás, segítség "háttérbe szoritotta azokat a kölcsönös elöitéleteket, amelyek a történelem viharos idöszakaszaiban a horvátokat és magyarokat esetenként egymással szembeállitották". ${ }^{32}$

A Magyar Köztársaság diplomáciai gesztusa nagymértékben meghatározta a zágrábi Hungarológiai Tanszék megalapításának szándékát. Nagykövetünk ezt az euforikus pillanatot érzékelve fordult hivatalosan „az illetékes horvát államigazgatási és tudományos intézmények [hez] és az egyetem vezetöi[hez] [...].” Kezdeményező fellépését a Bölcsészettudományi Kar Általános Nyelvészeti és Orientalisztikai Tanszékének vezetője, dr. Milka Jauk-Pinhak professzor asszony és a tanszék keretében működő magyar nyelvi lektorátus képviselője, dr. Sándor László egyaránt támogatta. 1993. október 29-én, az egyetem rektora és a nagykövet találkozója után a Bölcsészettudományi Kar dékánja, dr. Sonja Bašić és dr. Stipe Botica dékánhelyettes közreműködésével az év végére megteremtődtek a tanszékalapítás anyagi feltételei, s 1994. március 16-án az egyetem és a nagykövetség vezetője, Bagi Gábor nagykövet aláirhatta az alapító okiratot, amelynek 4. cikkelye értelmében „a Szerzödö Felek kölcsönösen támogatják a felsöoktatási intézmények közvetlen kapcsolatát, valamint a másik ország nyelvének, irodalmának, történelmének oktatását, amelyet oktatási intézményeikben a hungarológiai és kroatisztikai tanszékek és lektorátusok létrehozásával [...]. Lektorok, vendégtanárok cseréjével, könyvek, folyóiratok küldésével és szakmai továbbképzésekkel történö részvétellel segitenek. "33 Ezzel minden feltétel megteremtődött, hogy az 1994/95-ös tanévben a Zágrábi Egyetem Bölcsészettudományi Karán megkezdődjék a magyar nyelv és irodalom szakos képzés. A Hungarológiai Tanszéknek az Általános Nyelvészeti és Orientalisztikai Tanszékcsoport adott otthont, $s$ vezetője dr. Milka Jauk-Pinhak professzor asszony lett. A már státuszban lévő lektor mellé megérkezett két magyarországi vendégtanár is: dr. N. Goller Ágota az irodalomtörténeti, dr. Gadányi Károly a nyelvtudományi előadásokat tartotta. Már a második tanévben bekapcsolódott az oktatómunkába e sorok írója, két tárgykör előadásaival: A magyar irodalom európai kontextusban és A horvát-magyar irodalmi kapcsolatok története. Dr. N. Goller Ágota - nagy külföldi vendégtanári tapasztalatok birtokában - „[...] komoly részt vállalt a tanulmányi rendszer elökészitése kapcsán felmerült számos gyakorlati kérdés megoldásában". ${ }^{44}$ A képzés szerkezetét, rendjét, tanegységkínálatát a helyi egyetemi struktúra figyelembevételével alakították ki, amit

\footnotetext{
32 ANDrási Dorottya, „Néhány gondolat a Zágrábi Tudományegyetem Hungarológiai Tanszékének megalapításáról (Beszélgetés Bagi Gáborral, a Magyar Köztársaság 1992-1995 közötti első horvátországi nagykövetével a Zágrábi Tudományegyetem Hungarológiai Tanszékének megalapításáról)”, in Croato-Hungarica. Id. kiad.: 25.

${ }^{33}$ Uo., 27.

34 JaUk-Pinhak, „Hungarológiai szak... ”, 13.
} 
Jauk-Pinhak professzor asszony így foglalt össze: „A hungarológiai szak tanegység-kinálati struktúrája hasonló a karunkon müködö más filológiai stúdiumokéhoz: kétszakos képzésben négy tanulmányi évet elöirányzó szak. Arra törekedtünk, hogy a nyelvészeti, irodalmi és müvelödéstörténeti kurzusok megoszlásában bizonyos egyensúlyt érjünk el, azonban szem elött kellett tartanunk azt is, hogy hallgatóink nagy része elözetes nyelvtudás hiján kezdi el tanulmányait, igy a magyar mint idegen nyelv tanitását az alapoktól kell kezdenünk. A magyar irodalom, kultuira és civilizáció történetét feldolgozó tárgyakon kivül olyan tanegységeket is felvettünk a programba, amelyek keretén belül képet kapnak hallgatóink a magyar irodalom világirodalmi kapcsolatairól, midenekelött a horvát kultúrával és irodalommal való kapcsolaterendszeréröl. Szakunk oktatási programjának kidolgozásakor figyelembe vettük néhány magyarországi és más európai egyetem (Budapest, Debrecen, Pécs, Szeged, Bécs és Berlin) magyar szakos képzési konstrukcióját is. Elsödleges törekvésünk volt, hogy a hungarológiai tanulmányok magukba foglalják az uralisztika jó részét, igy a magyar és a vele rokon nyelvek összehasonlitó vizsgálatát is. Tapasztalatunk szerint ezek a szempontok aránylag kevésbé érvényesülnek Magyarországon kivül folyó felsö fokú hungarológiai oktatásban. Mindez nagymértékben hozzájárulhatott volna az egyes kroatisztikai témakörök elmélyültebb, összehasonlitó jellegü vizsgálatához is. Sajnos a gyakorlat és a tapasztalat arra kényszeritett bennünket, hogy a kari alapszabályzat heti óraszámkorlátozásainak függvényében ezen témák tárgyalását a Magyar nyelv története címü tárgy egyes fejezeteire csökkentsük." 35

Greksa a hungarológiai képzés 1903-1918 közötti periódusában a hallgatói érdeklődés gyér volta miatt panaszkodott. A 20. század utolsó évtizedében újra megindult magyar szakos bölcsészképzés oktatási kollektívája már az első évtized utolsó harmadában négy évfolyamon, kilencven körüli hallgatói létszámot tarthatott nyilván. ${ }^{36}$ A tanévenkénti érdeklődés kezdeti intenzitása évek múltán sem csökkent. A tanszék fennállásának huszadik évfordulóján a tanszék jelenlegi vezetője, dr. Žagar-Szentesi Orsolya megnyugvással konstatálhatta: a szakra jelentkezők létszáma évről évre huszonöt-harminc fő között mozog. ${ }^{37}$ Némi lemorzsolódás mellett egy-egy tanévben a létszám hatvan körüli, „[...] ami irigylésre méltó szám, amikor [...] némely külföldi hungarológián összehasonlithatatlanul kisebb a beiratkozottak száma". ${ }^{38}$

A képzés munkájában a kezdetektől meghatározó szerep jutott és jut az anyaországból jött vendégtanároknak. Minden tanévben két vendégtanár (gostprofesor) tartja az irodalomtörténeti és a nyelvészeti előadásokat, $s$ harmadikként a horvát-magyar irodalmi kapcsolatok történetét közel egy évtizeden át e sorok írója, majd őt követően dr. Lukács István. Az irodalomtörténet vendégtanárai voltak: Nagyné dr. Goller Ágota, dr. Lukács István, dr. Kiss Gy. Csaba, dr. Bene Sándor és dr. Virág Zoltán. A nyelvtu-

\footnotetext{
${ }^{35}$ Uo.

${ }^{36} \mathrm{Uo}$

37 Žagar-Szentesi Orsolya, A tanszék fennállásának 20. évfordulója alkalmából rendezett tudományos konferenciát bevezető előadása. Megjelenés alatt.

38 Uo.
} 
dományi tárgyak előadói dr. Gadányi Károly, dr. Nyomárkay István, dr. Lengyel Zsolt, dr. Nádor Orsolya, dr. H. Varga Márta voltak. Az 1999/2000-es tanév végéig uralisztikát tanított Pusztay János. E tárgy oktatása az említett tanévet követően megszűnt.

A vendégprofesszori státuszok újabban annyiban módosultak, hogy dr. Bene Sándor immár rendes munkaviszonyban tanít, ennek megnyitásával viszont megszűnt az irodalomtörténész vendégtanári állás. A nyelvészeti tárgyak vendégtanári állása változatlan. Szólni kell a lektori teendőket ellátó vendégoktatókról is, valamennyien magyarországi vendégek, a tanszék elmúlt két évtizedében Sándor László, Andrási Dorottya, Ladányi István, Durst Péter, Kiss Gabriella voltak e státusz birtokosai. Magyarországi vendégként vesz részt a tanszéki oktatómunkában Mann Jolán külső előadói minőségben. A tanszék hazai, tehát horvátországi személyi állományát Milka Jauk-Pinhak halála után és óta három oktató alkotja: Žagar-Szentesi Orsolya tanszékvezető, ĆurkovićMajor Franciska egyetemi docens és Kristina Katalinić egyetemi docens.

A relatíve nagy létszámú hallgatóság ismeretében felvetődik a kérdés: milyen az oktatás hatékonysága a nyelvismeret változó szintjét ismerve? Miként és mikor (mely évfolyamon) képes befogadni az ismereteket például az, aki a szak felvételével egy időben kezdi meg nyelvi tanulmányait? A kérdésre más és más választ adhat az, aki az első tanévben találkozik ezzel a hallgatói réteggel, illetve az, akinek előadásait a felsőbb, pl. a harmadik évfolyamon hallgatják. Kiss Gy. Csaba vonatkozó jegyzetében vegyes benyomásokat közöl mind az óralátogatás intenzitását, mind a tananyag elsajátítását, illetve nyelvismeretét illetően. Tapasztalata szerint zavaró a történelmi tájékozatlanság, az alapismeretek hiánya - kiváltképp a magyar históriát illetően, amely nyolc évszázadon át mégiscsak közös volt a horváttal. IV. Béla, Mátyás király, 1848, Kossuth Lajos ugyan jelen van ismereteik tárházában, de a huszadik század magyar kultúrájáról, történelméről szinte semmit sem tudnak. Ez persze idővel pótolható. Még nehezebb dolga van az előadónak az irodalomtörténet terepein, ahol olykor „keserves kipreparálniuk a hallgatóknak a Tartózkodó kérelem vagy $A$ közelito" tél sorait" ${ }^{39}$ Könnyebb a helyzet a negyedéves hallgatók esetében, ahol kiderül: „ki veszi komolyan magyar szakos stúdiumait”. 40 E sorok írója - kapcsolattörténeti tárgyából adódóan - kedvezőbb helyzetben volt. Ennek magyarázata egyfelől a tárgy időbeli elhelyezésében (harmadévesen veszik fel), másfelől a diszciplína anyagában rejlik. A vizsgán minden esetben megadtuk a lehetöséget: magyarul vagy horvátul kívánja előadni a hallgató mondandóját. Kivétel nélkül - a gyengébb nyelvismerettel rendelkezők is - a magyart választották, s csak olykor fordították a szót horvátra. E szubjektivitást sem nélkülöző vélekedés mellett fontosabb a kérdést két évtizedes távlatban szemlélni. Az 1994/95-ös tanévkezdéstől a máig eltelt közel negyedszázados oktatás történetét áttekintve markánsan kirajzolódik a képzés hatékonyságának szintje. Az eredmény például mérhető a hallgatóság műfordítói munkája s a tanszéken működő doktori iskola alapján. A nyelvileg felkészült, főleg felsőbb

${ }^{39}$ KIss, Oda-vissza, 32-33.

${ }^{40}$ Uo. 
éves hallgatók számára a tanszék évek óta meghirdeti a műfordítói szakszemináriumot. A foglalkozás vezetője dr. Curković-Major Franciska egyetemi docens. Ma már bátran leírhatjuk: e mühely résztvevői jelen vannak a horvát irodalomban, müfordításaik olyan vezető folyóiratokban látnak napvilágot, mint pl. a Horvát Tudományos és Művészeti Akadémia, immár fél évszázada folyamatosan megjelenő Forum címủ periodika vagy éppen a Književna smotra. Fontos és jelentős eredménye a fordítói közösség munkájának néhány klasszikus mü szöveghü transzlációja (Bánk bán, Az ember tragédiája, Csongor és Tünde), amelyek az oktatásban a szövegértést és értelmezést szolgálják. Ebbe a körbe tartozik egy, a 19. század magyar irodalmából készült szöveggyüjtemény, amely ugyancsak kiváló segédanyaga a tanszéki irodalomoktatásnak. Az impozáns kötet főszerkesztője Ćurković-Major Franciska, a szövegek fordítói: Ćurković-Major Franciska, Mitta Maltar, Ivana Pavlović, Lilla Trubics, Sandra Vitelić, Martina Kovačević, Ana Popović, Hrvoje Rastija, Helena Vučemilović-Vranjić, Antonija Žamić, Marina Miladinov, Ana Curković, Marina Kukina, Helena Miletić, Ivana Parlov, Martina Šestić, Sanja Šimatić, Annemari Ulamec, Maja Urban. Néhány versszöveg immár klasszikus transzlációja is szerepel a kötetben, alkotói: Dobriša Cesarić, Enver Čolaković, Željka Čorak, Horváth Béla, Mate Miloradaić. Žagar-Szentesi Orsolya tanszékvezető jogos büszkeséggel szólhatott a tanszék két, már végzett magyar nyelv és irodalom szakos hallgató költői sikereiről, mindketten nagyon előkelő költői díj birtokosai. ${ }^{41}$

A tanszék - noha a legfiatalabb külföldi hungarológiai műhely - már in statu nascendi célul tủzte mielőbb bekapcsolódni mind a hazai (horvátországi), mind a nemzetközi tudományos élet vérkeringésébe. Az oktatás megindítását követő harmadik tanévben magyar és horvát tudományos intézmények kutatóival együttműködve tudományos konferenciát szervezett, amelynek tárgya Dudits András munkássága volt (Dudits András - a horvát és a magyar humanista - Újabb kutatások). Lebonyolításában a Horvát Tudományos és Müvészeti Akadémia Történettudományi Intézete (Zavod za povijesne znanosti HAZU) és az MTA Irodalomtudományi Intézete voltak a partnerek.

A tudományos bemutatkozás újabb alkalma volt az MTA Irodalomtudományi Intézetével 1998 januárjában közösen szervezett tanácskozás (Baroque Concepts of History and National Identity in the Seventeenth and Eighteenth Century - Croatia and Hungary), amely „[...] föként Pavao Ritter Vitezović müveire - nemzeti identitással kapcsolatos felfogására és a magyar-horvát viszonyokkal kapcsolatos nézeteire [...]" koncentrált. ${ }^{42}$

A tanszék tudományos imázsának formálásában jelentős szerep jutott a 2001-ben a finnországi Jyväskyläben megrendezett V. Nemzetközi Hungarológiai Kongresszuson való részvételnek, amely az oktatói kollektíva sikeres nemzetközi bemutatkozása volt. ${ }^{43}$

E sikeres nemzetközi szereplés méltó folytatását jelentette egy újabb zágrábi konferencia megszervezése. 2002 a magyar-horvát kapcsolatok történetében „kivételes

\footnotetext{
41 ŽAGAR-SZENTESI, előadása.

${ }^{42}$ JaUk-PinhaK, „Hungarologiai szak...”, 14.

${ }^{43}$ Uo.
} 
évforduló” volt: Könyves Kálmán horvát királlyá koronázásának 900 éves jubileuma. A tanszék, amelynek tudományos programjában meghatározó a két nép közös hagyománykészletének feltárása, tudományos konferenciával és egy impozáns tanulmánykötet közreadásával ünnepelte „az európai történelem egyik leghosszabb ideig tartó állami unióját". A Croato-Hungarica címet viselö kötet megjelentetése további tudományos programadás is kívánt lenni: „A kivételes történelmi évfordulóra szánt kötetünket jelképesen elsö lépésnek tekintjük, egyben buzditásnak is kapcsolataink további kutatására. Abban a reményben, hogy Horvátország és Magyarország jószomszédsága példa lehet Közép-és Délkelet-Európában, és a közös szellemi tradició mind a két nép európaiságának méltó bizonyitéka" - olvassuk a Croatia et Hungaria címü bevezetőben. ${ }^{44} \mathrm{~A}$ kötet egyben számadás is volt. A „Bevezető rész” egyik textusa "Néhány gondolat a Zágrábi Tudományegyetem Hungarológiai Tanszékének megalapitásáról (Beszélgetés Bagi Gáborral, a Magyar Köztársaság 1992-1995 közötti elsö horvátországi nagykövetével a Zágrábi Tudományegyetem Hungarológiai Tanszéknek megalapitásáról)" a tanszék 1994-es újbóli megalapításának körülményeiről, működése első időszakáról kínál becses információkat. Már a kötet szerzőinek száma is (negyvenkettő) jelzi: interdiszciplináris kiadványról van szó, az irodalomtörténet, a nyelvtudomány, a néprajz, a képzőművészet, a sajtótörténet egyaránt jelen van lapjain, s csak természetes: nem egy esetben a komparatisztika szempontjai is érvényesülnek. A dolgozatok tematikája - ebből fakadóan - fölöttébb változatos. Legtöbbjük a horvát-magyar kapcsolatok köréből meríti tárgyát. A népes szerzőgárda tagjai között természetesen ott találjuk a tanszék mindazon horvátországi oktatóját és a magyarországi vendégtanárokat és lektorokat, akik az alapítás és a kötet megszerkesztésének időszakában részt vettek a tanszék munkájában: Milka Jauk-Pinhak, CurkovićMajor Franciska, Žagar-Szentesi Orsolya, N. Goller Ágota, Nyomárkay István, Lőkös István, Kiss Gy. Csaba, Andrási Dorottya, Mann Jolán. Ott vannak a szerzők sorában a tanszék későbbi vendégtanárai is: Bene Sándor és Lukács István s a magyar és a horvát néprajz, kroatisztika, illetve szlavisztika képviselői: Bojtár Endre, Kósa László, Fried István, Makkai Béla, Milosevits Péter, Ráduly Zsuzsa, Ress Imre, Sokcsevits Dénes, Ronkovics Attila, Udvari István és az olaszországi hungarológia képviseletében Amedeo Di Francesco, Ariana Quarantotto és Sárközy Péter. A hazai (horvátországi) kroatisztika, történettudomány, néprajz és művészettörténet élvonala: Stipe Botica, Hana Breko, Dalibor Čepulo, Jadranka Damjanov, Aleksandar Flaker, Jadranka Grbić-Jakopović, Marija Karbić, Mira Koler, Bulcsú László, Mijo Lončarić, Ivan Mirnik, Boris Nikšić, Ivo Pranjković, Diana Samardžija-Vukičević, Andrea Sapunar, Vlasta Švoger.

E népes szerzőgárda dolgozatai tárgyának spektruma igen széles: a háromegy királyságbeli magyar pénzforgalom; a horvátországi és szlavóniai nemesség és Magyarország viszonya; a Kossuth-Tkalac-párhuzam; a 19. századi horvát liberális sajtó magyarságképe; a bán jogállása a Saborban és a horvát autonómia; a szétválás előtti magyar-horvát

${ }^{44}$ Croato-Hungarica..., 5. 
viszony; a horvát kisnemes és magyar foúrból lett horvát bán: Litvai Horvát Damján; az esztergomi érsekség és a zágrábi püspökség középkori liturgikus zenei kapcsolatai; Paulus Hungarus/Dalmata; a bolognai Magyar-Illír Kollégium; Pavao Ritter Vitezović és Fernando Marsili; a horvát református falu: Tordince; a magyarországi horvátok; a Mária Terézia-féle úrbérrendezés forrásainak délszláv nyelvű változatai; egy burgenlandi horvát prédikáció magyar és német vonatkozásai; Asbóth Oszkár Rešetar szerb (horvát) nyelvtanáról írott munkája éppúgy tárgyai a dolgozatoknak, mint Ivan Bojničić első horvátországi magyar grammatikája és a magyar, a horvát és a lengyel nyelv tükörszavai; a magyar kroatista nyelvészek; a burgenlandi E. M. Kragel „Csetvero-versztni duhovni persztan" című munkája; a magyar sors a 16. századi horvát irodalomban; a horvát felvilágosodás íróinak magyar témái; a horvát himnusz (Lijepa naša) közép-eruópai kontextusa; Durazzói Károly irodalmi és históriai ábrázolása; Horvátország, Magyarország és Olaszország képe Madách „irodalmi földrajzában”, József Attila és a cseh költészet intertextuális játékai; Sinka István és Krleža balladái; Molnár Ferenc horvát és magyar kritikai recepciója; Đuso Šimara Pužarov kétnyelvű költészete; Kálmán herceg csázmai képzőművészeti és írásos emlékei; Ksaver Šandor Gjalski műveinek magyarságképe; a magyar millennium és a horvát közvélemény; zágrábi útirajzok; a Csontváry-életmű vizuális és tartalmi elemzése; A. G. Matoš magyar vedutái; Fejtő Ferenc „Érzelmes utazás” címủ zágrábi útirajza; Krleža magyar vedutái; továbbá Nyomárkay István, Lukács István egy-egy művének méltatása s a Sufflay-életmű újabb interpretációinak recenziója.

A kroatisztika, a hungarológia és a komparatisztika művelőinek e demonstratív felvonultatása a tanszéki kollektíva fölöttébb figyelemre méltó szervezőképességét dicséri, az impozáns, küllemében is reprezentatív kötet pedig a Zágrábi Egyetem és a Matica hrvatska kiadójának munkáját.

Kérdés: a 2002 óta eltelt évek milyen további eredményeket hoztak a tanszék életében. Az előzőekhez hasonló számvetés 2014-ben történt a tanszék fennállásának húszéves jubileuma alkalmával. Az ünnepi eseményt természetesen újabb tudományos ülésszakkal tisztelték meg, a tekintélyes zágrábi világirodalmi folyóirat, a Književna smotra lapjain a szélesebb horvát közönséget informálták a hungarológiai műhely munkájáról. A tudományos ülésszak anyagának megjelenése még várat magára, a folyóirat magyar száma viszont a megjelenés rendje szerint 2015-ben napvilágot látott (Književna smotra: Časopis za svjetsku književnost, Godište XLII/2015 broj 147(3). 3-194.). A lapszámot összeállító kollektíva ezúttal is mintaszerü munkát végzett. Kéttucatnyi szerző eredeti munkája a tanszék tudományos és műfordítói tevékenységét reprezentálták, a szépirodalmi szemelvények sorával pedig a kortárs magyar irodalom széles választékát az olvasóknak. A közreműködő szerzők között ezúttal is jelen vannak mindazon vendégtanárok, akik a kezdetektől a folyóirat megjelenéséig a tanszék oktatói voltak. A tanulmányok tematikája változatos. Nádor Orsolya a hungarológia fogalmi definiálása mellett áttekinti a diszciplína történetét is a 20. század első felétől napjainkig. A magyar lapszám „A magyar irodalom évszázadai” címủ blokkjában Bene Sándor Zrínyi Miklós és Péter Zrinyiászainak komparatív elemzését adja; Kiss Gy. Csaba Jókai 
fiumei kapcsolatáról értekezik; Virág Zoltán Kosztolányi „Esti Kornél” című művében a víz szimbolikáját elemzi; Szilágyi Zsófia a női identitás Kosztolányi-művekben megjelenő rajzát; Ćurković-Major Franciska pedig vitéz Somogyváry Gyula első világháborús trilógiájának (Virágzik a mandula, Ne sárgulj füzfa, És Mihály harcolt) karlovaci (károlyvárosi) témavilágáról informál a horvát társadalomtörténet avatott ismerőjeként.

A horvát-magyar irodalmi kapcsolatok történetében sajátos fejezetet alkot Miroslav Krleža életműve. Lőkös István és Lukács István dolgozatai a Krleža-œuvre kutatásának új dimenzióira, lehetőségeire irányítják a figyelmet: az előbbi szerző Krleža háborús naplójegyzeteinek antimilitarista, szociológiai aspektusaival foglalkozik, míg Lukács István a Zászlók címủ monarchiaregény filozófiai gyökereit nyomozza. Tverdota György József Attila műveiben a szegénység problémájának költői ábrázolására összpontosít, míg N. Goller Ágota a meseszerűség és valóság problémájának világirodalmi vetületét elemzi.

„A kortárs irodalmi témák és a müforditás kérdése” címủ blokk írásainak sorát Ludányi István dolgozata nyitja, aki $A z$ utolsó farkas című Krasznahorkai László-regény motívumainak struktúrájára összpontosít; Medve Zoltán a horvát és a magyar irodalomban megjelenő háborús traumákat és a politikai dimenziókat analizálja. Danijela Marot Kiš Kertész Imre Sorstalanság című regényét méltatja, Toldi Éva és Neven Ušumović a diaszpóra magyar irodalmára nyit ablakot Bodor Ádám és Gion Nándor egy-egy művét interpretálva.

Fontos írás Mann Jolán a horvát-magyar irodalmi kapcsolatok történetében oly meghatározó szerepet játszó Enver Čolakovićnak munkásságát méltató dolgozata. Čolaković a 20. század második felében a magyar poézis teljes spektrumát reprezentáló költői antológia fordítója-szerkesztője volt. Žagar-Szentesi Orsolya és Kristina Katalinić munkája Kukorelly Endre egy műve kapcsán (Rom - A komonizmus története) a müfordítás fordítástechnikai problémáit taglalja.

A folyóirat „magyar számát” "A magyar menyasszony” című blokk zárja, amely a Ćurković-Major Franciska vezette műfordítói szakkollégium résztvevőinek tolmácsolásában Borbély Szilárd, Kemény István, Térey János, Rakovszky Zsuzsa, Dragomán György, Tóth Krisztina, Háy János műveiből válogatott szemelvényeket tartalmaz.

A tanszék történetének felvázolásakor szólnunk kell arról a kutatási programról is, amely az MTA támogatásával működik, s amelynek tárgya a horvátországi magyarság nyelvének kutatása. A munkában az oktatók mellett a nyelvészet iránt érdeklődő hallgatók is részt vesznek.

Végezetül a tanszéki tudományos tevékenység egy újabb eredményét is konstatálnunk kell: egy frazeológiai szótár közreadását, amely az alábbi szerzők közös munkája: Antonija Jelavić, Darija Klinac, Eva Hoyt-Nikolić, Kiss Gabriella, Nikola Kušćer. A mü címe: "Szivvel-lélekkel/Dušom i srcem. Magyar-horvát szomatikus szólástár/Madarskohrvatski rječnik somatskih frazema." A reprezentatív kiállítású könyv bemutatója 2018. március 26-án volt a Zágrábi Magyar Intézetben a tanszék és a Balassi Intézet közös szervezésében... 